\title{
THE CHARACTERISTICS AND COMPLEXITY OF THE NIGERIAN SECURITY CHALLENGES: THE NEED FOR A NEW STRATEGY
}

\author{
Etebom John Monday \\ Department of Local Government and Development Studies, Obafemi Awolow University, Ile Ife, Nigeria \\ Correspondence Author: jmetebom@oauife.edu.ng
}

\begin{abstract}
Abstrak: Nigeria, negara terpadat keenam di dunia, menghadapi serangkaian tantangan keamanan seperti kebanyakan negara berkembang di Afrika Barat, Afrika Utara, dan Timur Tengah. Tingkat ketidakamanan di Nigeria telah meningkat ke tingkat yang belum pernah terjadi sebelumnya. Tidak ada bagian dari enam zona atau wilayah geopolitik yang bisa dikatakan aman. Tantangan keamanan di setiap wilayah negara sedikit terintegrasi dan aneh juga. Dari pemberontakan, terorisme, bandit hingga gemerisik ternak di Utara hingga konflik petanipenggembala, penculikan, perampokan bank, agitasi pemisahan diri dan separatis di Selatan negara itu. Tidak ada bagian dari negara yang bebas dari ketidakamanan. Studi ini menyelidiki karakteristik tantangan keamanan yang dihadapi negara dan menganalisis kekhasannya di enam zona geopolitik. Studi tersebut mengungkapkan bahwa tantangan keamanan yang melanda negara diciptakan di dalam negeri dan saling terkait. Sebaliknya, itu akan membutuhkan beberapa pendekatan sosial-politik militer yang dinamis dan pragmatis dalam negeri untuk memadamkannya. Studi ini mengadopsi metode analisis kuantitatif dan mengambil manfaat dari wawasan dan pengalaman penulis yang pernah bertugas di militer Nigeria. Lebih lanjut merekomendasikan keamanan inklusif baru dan strategi politik untuk memadamkan pemberontakan di negara tersebut.
\end{abstract}

Kata kunci; Kompleksitas; Pemberontakan; Pembajakan; Keamanan; Persatuan.

\begin{abstract}
Nigeria, the world sixth most populous nation, is faced with an array of security challenges like most developing nations in West Africa, North Africa and the Middle East. The level of insecurity in Nigeria has risen to an unprecedented level. No part of the six geopolitical zones or regions could be said to be safe. The security challenges in each region of the country are slightly integrated and peculiar as well. From insurgency, terrorism, banditry to cattle rustling in the North to farmer-herder conflict, kidnapping, bank robbery, secessionist and separatist agitations in the South of the country. No part of the country is free of insecurity. The study investigated the characteristics of the security challenges confronting the country and analyzed its peculiarities in the six geopolitical zones. The study revealed that the security challenges ravaging the country were domestically created and interrelated. Inversely, it would require some domestic dynamic military cum pragmatic socio-political approaches to quell. The study adopted a quantitative method of analysis and drew from the benefit of insight and experience of the author who had served in the Nigerian military. It further recommended new inclusive security and political strategies for quelling the uprising in the country.
\end{abstract}

Keywords: Complexity; Insurgency; Piracy; Security; Unity.

Article Information: Submitted: 2021-11-26; Revised 2021-12-26; Accepted: 2022-01-31

\section{INTRODUCTION}

Nigeria pride itself as the giant of Africa owing to its large population, vast landscape, human and material resources. Since her independence on October 1, 1960, from Britain, the Nigerian State has been faced with several challenges beginning with her struggle to remain a single indivisible entity barely six years into her post-independence history to military intervention in politics that span almost three decades, political violence in 1983 that led to the collapse of the second republic, minority agitation for recognition as equal players in the Nigeria project. (Mustapha, 2005; Adeniyi, 2012; \& Etebom 2021).

Aside from the Nigerian civil war between 1967 to 1970, no national issues have threatened the corporate existence of the Nigerian State, like the insecurity currently bedevilling the country. The country had witnessed and overcame the civil war, military intervention in politics, political unrest,

\section{(cc) BY-SA}

This work is licensed under a

Creative Commons Attribution-ShareAlike 4.0 International License. 
intra-ethnic, inter-ethnic, religious and communal conflicts (Haldun \& Opeyemi, 2016; Duerksen, 2021; Segun, Gberevbie \& Kester, 2021; Etebom, 2021).

None of these security challenges come near the unprecedented level of insecurity currently confronting the country on all fronts. From the Boko Haram insurgency, which began in the North East in 2012, to banditry and the alarming rate of the mass kidnapping in the North West where schools are been shut down to mass killings in the North Central due to farmers-herders conflicts and ethnic clashes causing food insecurity in the country. The South West and South-South regions are witnessing deadly conflicts of farmers-herders, attacks on government installations, jail breaks, and other security challenges. The secessionist agitation in South East and the separatist activities in the South West are major security threats to the territorial integrity of the Nigerian State. The activities of Pirates on the Gulf of Guinea have increased. The threat of insecurity has become so real that no zone out of the six geopolitical zones is safe.

The Nigerian military, supported by its paramilitary forces, have been in the lead, battling to quell the rising level of insecurity in the country. The Nigerian government has spent lots of its resources in purchasing weapons and military hardware. The President Goodluck Jonathan administration hired foreign mercenaries to end the Boko Haram insurgency. The Lake Chad Basin states comprising Cameroon, Chad, Benin, Niger and Nigeria established the Multinational Joint Task Force; the states of the North East established the Civilian Joint Task Force; State governments-owned security outfits and traditional institutions are all involved in the fight against insecurity in the country. Unfortunately, despite all of these efforts, the level of insecurity in the country is at an unprecedented level. The study investigated the characteristics of the crises with a view of understanding the situation, analyzed its complexity and concluded with workable recommendations and strategies that will halt the rising rate of insecurity in the country.

\section{THE NIGERIAN STATE}

The history of the Nigerian State dates far back to the pre-colonial era. It became home to several indigenous pre-colonial kingdoms and states during the second millennium $\mathrm{BC}$, with the Nok civilisation in the $15^{\text {th }}$ Century. The history of the entity known as Nigeria can be traced to the amalgamation of the Southern and Northern Protectorate by Lord Lugard in 1914. Before the amalgamation, the Pre-Colonial Nigerian state was dominantly the Hausa-Fulani Emirate in the North, the Yoruba Kingdom in the West and the Igbo kingdom in the East. There were other kingdoms like the Great Benin Kingdom, among others. The name 'Nigeria' was coined by Flora Lugard, meaning the Niger Area. The amalgamation of 1914 divided the country into two major divisions, i.e. Southern Nigeria and Northern Nigeria. It is worthwhile to mention that Great Britain colonised Nigeria. She gained her independence in 1960 and became a republic in 1963. Nigeria is officially referred to as the Federal Republic of Nigeria located in West Africa, geographically between the Sahel to the North and the Gulf of Guinea to the South in the Atlantic Ocean. Nigeria is the most populous nation in Africa, with an estimated population of over 2 million, covering an area of 923,769 kilometres. Benin borders Nigeria in the West, Niger in the North, Cameroon in the East and Chad in the North East. Nigeria is a heterogeneous state with more than 25 ethnic groups and hundreds of distinct languages.

The Nigerian State began its political journey and quest for national development along three regions: Western, Northern, and Eastern. The Midwest region was later created in response to the agitations of the minority groups in parts of the Northern and Western regions. The military intervened in Nigerian politics in January 1966 and another counter-coup in July of the same year. The aftermath of the coup and counter-coups in 1966 was a civil war between 1967-1970. The country's political structure was changed from 4 regions to 12 states by the General Yakubu Gowon administration in 1967. The General Murtala/Obasanjo administration increased the number of states from 12 to 19 in 1976. The general Ibrahim Babangida military administration created 11 more states taking the total number of states in the country to 30 . The administration also moved the Federal Capital Territory from Lagos to Abuja, its present location, in 1991. The General Sani Abacha Administration created six more states bringing the total number of states to 36 . It is important to mention that the 36 states in the country were created by the military and not by civilian-led government. The administration also divided the country into 6 Geopolitical zones as follows:

\section{(c) BY-SA}

This work is licensed under a

Creative Commons Attribution-ShareAlike 4.0 International License. 


\begin{tabular}{|l|l|l|l|l|l|}
\hline North West & North Central & North East & South West & South-South & South East \\
\hline Kaduna & Niger & Bauchi & Ekiti & Akwa-Ibom & Enugu \\
\hline Kastina & Kogi & Borno & Lagos & Edo & Imo \\
\hline Kano & Kwara & Gombe & Osun & Delta & Abia \\
\hline Kebbi & Plateau & Taraba & Ogun & Bayelsa & Ebonyi \\
\hline Sokoto & Nasarawa & Adamawa & Ondo & Rivers & Anambra \\
\hline Jigawa & Benue & Yobe & Oyo & Cross -River & \\
\hline Zamfara & & & & & \\
\hline
\end{tabular}

Nigeria is politically divided between the South and North. The South comprises 3 Geopolitical zones, i.e. the South West, South East and South-South with 17 states, while the North has 3 Geopolitical zones comprising the North Central, North East and North West with 19 states. There are three major ethnic groups: the Hausa-Fulani in the North, Yoruba in the West, and Igbo in the East. The official language in the country is English. The country is home to some of the world largest population of Muslims, mostly in the North while Christians are largely in the South. The Nigerian constitution ensures freedom of religion and association. The Nigerian economy is the largest in Africa and is mainly dependent on oil from the South of the country. The military government largely ruled the country in its post-independence era. The military was in charge from 1966 to 1979 and returned in 1983 to 1999. The country was under civil rule from independence in 1960 to 1966, 1979 to 1983 and returned to democratic rule in 1999 referred to as the fourth republic. (Adeniyi 2010; Etebom 2021).

\section{PECULIARITIES OF THE NIGERIAN STATE}

To understudy the security challenges in Nigeria, there is the need to have a clear understanding of the peculiarities of the Nigerian State. As mentioned earlier in the study, the country was colonized by the British in three distinct regions where the styles of governance applied varied. The British used indirect rule during the colonial era. The Hausa-Fulani operated a centralized system of local administration before the arrival of Britain. The Emirs were the heads of each emirate, and the people were largely answerable to him. They were mainly Muslim communities. Indirect rule was a huge success in the Hausa-Fulani Emirate. The structure was slightly different in the Yoruba Kingdom. Although the Yoruba had a well-organized system of local administration that predates colonialism, it was more of a decentralized system. The Oba's (Kings) of Oyo is the head of the entire Yoruba Kingdom. The pre-colonial Yoruba kingdoms were largely traditional worshippers, with the introduction of Christianity partially embraced. Indirect rule was a success in the Yoruba Kingdom. The structure was different in the Igbo kingdom. There was no clear cut organized system of local administration in Eastern Nigeria before colonialism. This accounted for the near failure of indirect rule in the region.

After independence, the three dominant regions developed at a different pace, with a government at the centre coordinating the country's affairs. The West embraced education and offered free education in its region. The East embraced education and trade. The North largely maintained the centralised system of administration. Western education was mainly for the children of the privileged in the North while the East embraced education and trade.

The military intervention in 1966 changed the system of government in the country. Ekeh argued that military intervention had adverse effects on the development of the country. The military introduced a form of unitary federalism in the country by breaking the regions into states answerable to the Head of State and commander in chief of the armed forces (Adeniyi 2010). The differences amongst the various regions in the country, the divide along ethnic and religious lines were not evident until the military coup and counter-coups of 1966.

After almost three decades of military rule, the country returned to democratic rule in 1999. Unfortunately, Nigeria's story in the fourth republic is a clear divide along ethnic and religious lines. With 36 states in the country, 19 located in the North and 17 in the South, each having three geopolitical zones. Northern Nigeria is largely populated by Muslims and Hausa-Fulani herders with minority ethnic groups and Christians majorly in the North Central zone and Southern Kaduna. Southern Nigeria is structurally complex. The South West are majorly Yorubas; the South East are Igbos while the SouthSouth is more heterogeneous with different minority ethnic groups in each of its six states. The Nigerian

\section{$($ c) $)$ BY-SA}

This work is licensed under a

Creative Commons Attribution-ShareAlike 4.0 International License. 
State has become highly divided along ethnic, political and religious lines to the actions and inactions of the political class. The 2015 presidential elections was majorly a contest between two leading candidates; Goodluck Jonathan, the incumbent from Southern Nigeria of PDP and Gen Muhammadu Buhari of the APC from Northern Nigeria. The results of the elections showed that the voting was done along political, ethnic and religious lines. Gen Buhari won all the seven states in the North West (his geopolitical zone), North East and the four states under the control of his political party in the South West. On the other hand, Goodluck Jonathan also won all the votes in his South-South geopolitical zone, the South-East states and the minority and Christian dominated in North like Taraba, Plateau and Nasarawa. These divides have encouraged and fueled the diverse rising insecurity in the country. No geopolitical zone can be said to be safe and free from security threats in Nigeria. The current security challenge confronting the country is traceable to the actions and inactions of the political class in the fourth republic. Although, that is not to say the security challenges bedeviling the country started this period. However, it escalated to the current unprecedented level during this period.

\section{SECURITY CHALLENGES IN THE GEOPOLITICAL ZONES}

The North East: This zone is the most insecure revenge zone in the country. It is home to the dreaded terrorist group Boko Haram whose activities began as a Jihadist Islamic sect in 2002. Amongst the sects' objectives was the proclamation of western education as a sacrilege. After the unjust extrajudicial killing of its founder, Yusuf Mohammed and other members in the hands of the Nigeria police; the group began to carry out large scale violent acts against the State to avenge the killings. They began by attacking police posts, using suicide bombers to attack large gatherings of worshippers in the State and security agents. Duerkson 2021 argued that Boko Haram has an offshoot called the Islamic State in West Africa (ISWA), a more deadly terrorist group revamping the country's North East. These terrorist groups have killed thousands of civilians and military personnel in the zone. Their activities are still on despite the onslaught by the military, Multinational Joint Task Force and the joint civilian task force formed by the state government. The criminal and violent activities of Boko Haram have spread to other states in the zone and beyond to the North-West states of Kano, Sokoto and parts of Adamawa. There is a breakaway faction of the group called Ansaru; they use Fulani-herders to attack schools, farm settlements, residential areas and places of worship. They carry out mass kidnapping in exchange for money. There is a high rate of cattle rustling in the zone. The sects have occupied some parts of Borno State; they force residents and locals to pay taxes to them. The recent violent trend of Boko Haram and its affiliated terrorist groups killings of military and paramilitary personnel in the zone, mass kidnapping of males who are forced to join the group, and collecting taxes from locals. Gombe state is the only state with relative peace and a low rate of insecurity in the zone. The security havoc of Boko Haram has spread to neighboring states and countries inclusively, such as Niger, Chad and Cameroon.

The North Central: Historically, the North Central states of Benue, Nassarawa, Plateau and Niger have been the fertile plains and grazing lands for nomadic, pastoral and sedentary agriculturalist groups in the country (Duerken, 2021; Sylvanus \& Ifeadi, 2012). Unfortunately, today farmers have deserted their farmlands and ancestral homes due to attacks and killings by Fulani herders. Benue state is the most hit in the zone. The State has witnessed mass killings of its citizens, with thousands displaced. The story is not different in the Plateau (Southern Jos), where killings and castle rustling have continued unabated. The leadership of the state house of assembly recently accused the State Governor of Negligence. A member of the House of Representatives called the continuous killings in Southern Jos a genocide against his people (Premium Times, September 14, 2021). The highways are not safe for travellers with bandits and armed robbers having a free day. No state in the zone is free of either herderfarmer conflicts, bandit activities or communal clashes. The forests in Niger state has turned into a war zone between the military and bandits. The bandits use the vast forest as a hideout to carry out mass kidnapping in exchange for ransoms. The State Governor, Abubakar Sani Bello, recently cried out for help, he said more than five towns/villages in the state have been deserted due to the activities of bandits (Vanguard, April 26, 2021). The activities of the bandits have continued with many security personnel paying the supreme price of death in the cause of duty in the zone. The twin states of Kwara and Kogi are faced with communal clashes, killings, farmer-herder conflicts and bank robbery.

\section{$(\infty))$ BY-SA}

This work is licensed under a

Creative Commons Attribution-ShareAlike 4.0 International License. 
The North West: the North-West State of Kastina, Sokoto, Zamfara and Kaduna are the epicentre of bandit activities in the country. Bandits have created a huge business in the zone through mass abduction from schools and kidnapping families and traditional leaders. In Zamfara State, the activities of the bandits, which included the abduction of people from all wakes of life and castle rustlings, made the federal government declare the State a "no-fly zone" in March 221. The state government, in a bit to stamp the rampage of the bandits, shut down the telecommunication networks and ordered the closure of all weekly markets in the State in a desperate move to quell the havoc of bandits. Disappointedly, despite all these measures coupled with the military's campaign, the activities of the bandits are on the increase in the State and zone at large. The activities of the bandits are worse in Katsina state, the home state of President Buhari. The negotiation between the State Governor and the bandits failed. The state governor, Aminu Masari, on August 221 asked citizens of the State to take up arms and defend themselves against the bandits in the State. Bandits have ambushed and killed hundreds of security agents in the zone.

The story is worse in Kaduna State; the activities of the bandits have led to the closure of schools in most parts of the State. Parents pay huge sums to have their children released after mass abductions, and other criminal activities like kidnapping and assasinations in the State is fast becoming a norm. The activities of herders in southern Kaduna populated by Christians, is worrisome. Mass killings have continued unabated in southern Kaduna. No part of the State is safe; the bandits recently invaded the Nigerian Defence Academy. They killed a senior officer and abducted another released days after an alleged negotiation between the bandits and his friends. The highways have been abandoned for rail transportation in the state. The railways no safer; a train from Abuja to Kaduna was on October 22 2021, attacked by a bandit (Daily Post, October 23, 2021). Kaduna state is home to most military training institutions in the country, yet the killings and mass abductions in the state have increased recently. The activities of criminal elements in the State have increased to an unimaginable level. The city centre is not spared as unknown gunmen are assassinating prominent citizens in the State. The recent assassination of Air force marshal Muhammed Masaka and his grandson in his home town in Kaduna State shows the helpless State of insecurity in the zone. (The Guardian, November 9 2021). Sokoto state is also witnessing mass killings of natives by bandits. They attack villages, abduct and carry out mass killings. They launched attacks on military formations in the zone and killed soldiers and policemen. The situation is the same in Taraba state where a former Chief of Defence Staff and Minister of Defense, General T.Y. Danjuma, called on his kinsmen in the state to arise and defend themselves against the Fulani led ethnic cleansing in the country and the State in particular due to the senseless mass killings (Vanguard, March 24, 2018). The level of insecurity in the North-West zone is at an alarming rate. Kano state has its share of insecurity. The treacherous activities of the bandits and Boko haram have continued unabated by the government in the zone.

The South East: the South East is the most homogeneous zone in the country. It is home to the Igbos, who are dominantly Christians and traders. There are issues of deadly farmer-herder clashes in Ebonyi and Abia states the zone. The clashes reduced after the Eastern Security Network, the paramilitary arm of IPOB, declared an end to open grazing in the zone. The business of kidnapping for ransom began in the zone of the country. There are cases of senseless killings of prominent citizens and clergy in the zone as well. Although, the major security challenge in the zone is the activities of the Biafran successionist agitators led by the Indigenous People of Biafra (IPOB).

Goggins (2017), argued that the Igbos felt cheated in the tripartite matrimony of the Yoruba, Hausa-Fulani and Igbo that constitutes the major ethnic groups in the country. The perceived marginalization, which seems not to have been corrected despite the civil war (1967-1970), led to the emergence of IPOB. The arrest and detention of its leader, Nnamdi Kanu and its subsequent classification as a terrorist organization and proscribed when it had not engaged in any violence made the group embrace violence. The release of Nnamdi Kanu and the onslaught of the military to quell their activities gave birth to the Eastern Security Network, which began to launch attacks on government installations, institutions and military posts. The action of the government made the group resort to violent activities. The confrontation between the group and the military has led to the death of hundreds of youths in the zone and dozens of deaths in the military. The weekly sit-at-home orders by IPOB have adversely affected the zone's economic fortunes and the country at large. The threat of a sit-at-home order issued by IPOB in the build-up to the November 2021 Anambra governorship election to press

\section{$(\boldsymbol{C o})$ BY-SA}

This work is licensed under a

Creative Commons Attribution-ShareAlike 4.0 International License. 
home the release of its leader, Nnamdi Kanu, who was rearrested in Kenya led to the over militarization of the state. The Nigeria police deplored about thirty-two thousands of its men and officers to the state to ensure the surety of lives and properties during the election. IPOB later withdrew the orders a day to the election. The elections were peaceful. IPOB agitation has continued with traditional rulers and elites calling for dialogue between the agitators and the government. No state in the zone is free from security threats either IPOB or other criminal elements killing and robbing banks. The activities of IPOB have increased lately because its leader is still in detention.

The South West: The zone is renowned for its educational advancement. It is home to the Yoruba ethnic group made up of traditional worshippers, Christians and Muslims. The security challenges in the zone are majorly robbing banks and killing security personnel and innocent citizens in the process; kidnapping for ransom with few cases of killings of kidnap victims. There are deadly farmer-herders clashes in Ondo, Oyo, and Ogun states. The signing into law the Anti-Open Grazing law by the Governors in the zone have reduced the frequent farmers-herders clashes in the zone. Although farmers have deserted their farmlands in parts of Ogun and Oyo states, the issue is gradually been resolved. The major security threat to the Nigerian State in the zone is the successionist agitation led by Mr Segun Adeyemo with the support youths at home and in the diaspora calling for the creation of Oduduwa Republic. The activities of the agitators were getting wide attention in the zone before the federal government clamped down on them by invading the home of its leader and his subsequent arrest and detention in the Benin Republic. The activities of the successionist group have reduced since the detention of its leader. The End Sars Movement has its root in the South-West zone. The zone is relatively the safest in the country; night travelling are death traps, pockets of kidnappings and bank robbery are ongoing. The establishment of the State-owned security network, Amotekun, has helped reduce the rate of insecurity in the zone.

The South-South: The South-South is the most heterogeneous zone in the country. The six states in the zone are house to different minority ethnic groups in the country. The common link in the zone is Christianity, though with different doctrines. It is one of the zones with a lesser number of indigenous Muslims in the country. The security challenges in the zone are peculiar; the zone accounts for more than $75 \%$ of oil production, which is the country's major source of government revenue. There are high levels of criminal activities like robbery and kidnapping across the zone. Delta and Edo are witnessing deadly farmers-herders clashes. There are senseless killings in Cross Rivers states resulting from communal clashes intra-state and inter-state with border towns in the Ebonyi States. The Eastern Security Network (IPOB paramilitary group) extended its treacherous activities to Akwa-Ibom and Cross Rivers states. They attack police stations, kill military personnel and carry out jailbreaks. No sit at home order in the South-South.

Rivers state is home to another separatist group, the Movement for the Actualisation of the Sovereign State of Biafra (MASSOB); it is a militia group that operates mainly in Rivers State, the South East and Akwa Ibom State. Oil theft and bunkering are twin activities in the oil-rich region. Oil pipeline vandalisation has reduced with the introduction of the Federal Government Amnesty Programme of the Umaru Musa Yar'Adua administration in 2009. The activities of pirates in the Gulf of Guinea is a major security concern in the zone. Piracy in the Gulf of Guinea recently accounts for over 95 per cent of crew members kidnapped in the world, with over 35 per cent recorded piracy events on the coast of Nigeria in 221 (Duerken, 2021). No state in the zone is free from security threats.

The above analyses of the state of insecurity in each geopolitical zone revealed that the security challenges are domestically created and related in most parts of the country. The security challenges in Northern Nigeria is peculiar and largely different from Southern Nigeria, where successionist groups and agitators are holding sway. The business of kidnapping has spread across all zones in the country, owing to its lucrative nature. Bank robbery is more pronounced in the South West and South East while cattle rustling is a northern security challenge.

Below is a Map Security Threats and Spread in the Six Geopolitical Zones in the Country: 


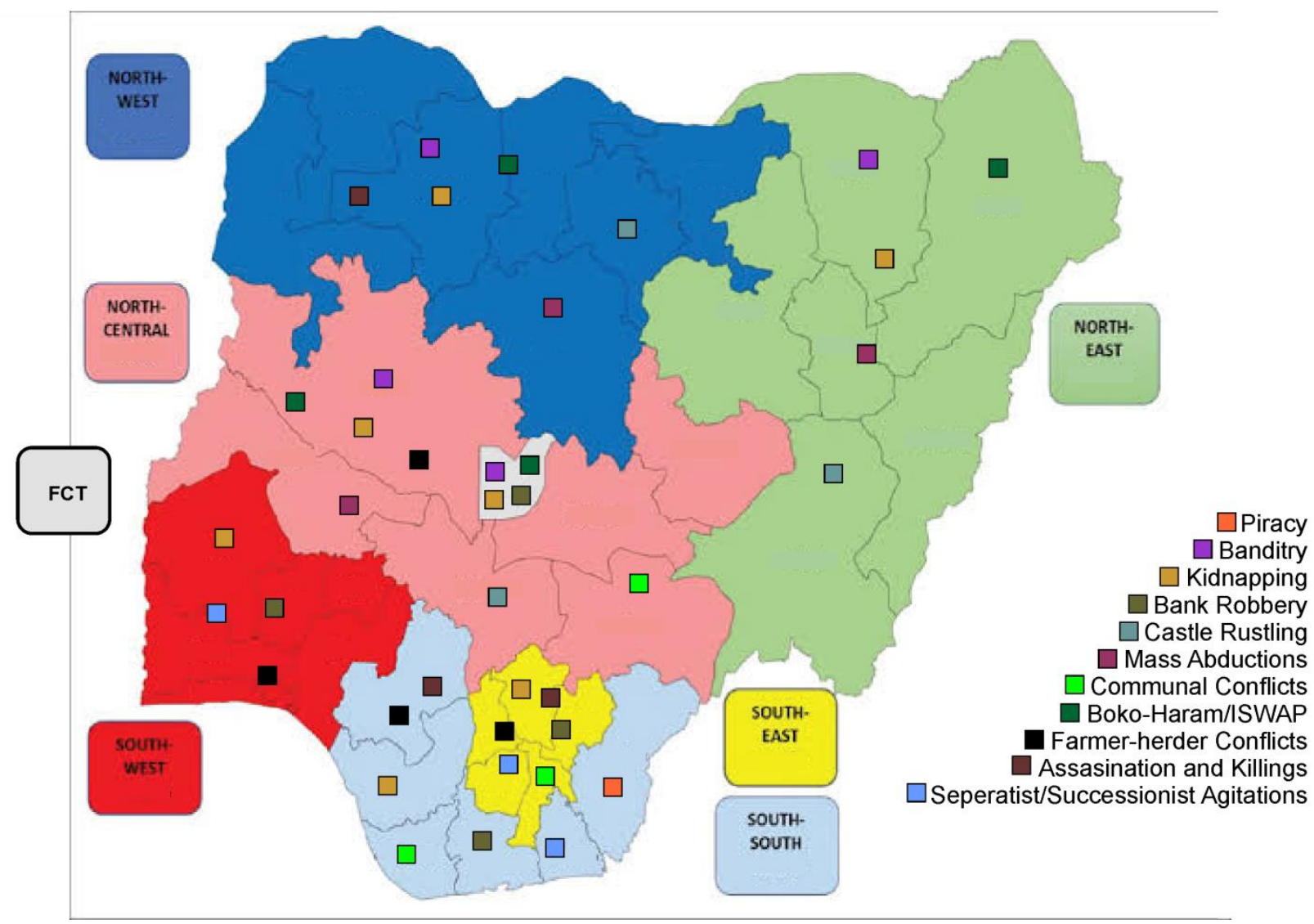

Source: Author, 2021

\section{THE NEW STRATEGY}

The Nigerian Military (The Army, Airforce and Navy) with its paramilitary forces (the Nigeria Police, Civil Defense Corps, Customs and Immigration Services) backed by the Multi-National Joint Task Force comprising of the Lake Chad Basin states (Cameroon, Chad, Benin and Niger) and the Civilian Joint task Force and other security outfits created by state governments in the country are all involved in the fight to quell the rising level of insecurity in the country. Unfortunately, despite all these efforts, insecurity is at an unprecedented level historically in the country. With the records of the Nigerian military achievements in peacekeeping missions (United Nations and ECOMOG) in some parts of Africa, one would have expected that the military should have quelled the rising rate of insecurity in the country. It calls for an holistic reassessment and appraisal of the tactics employed by the Nigerian State in the fight against insecurity across the country.

Having understudied the characteristics and peculiarities of the security challenges in the six geopolitical zones coupled with the benefit of insight as an ex-military personnel. There is a need for a new strategy due to the country's domestic nature, interrelatedness, and spread of insecurity. The new combined strategies, if implemented, would bring to an end the menace of insecurity in the country. Military onslaughts alone have not been able to quell the unprecedented rate of insecurity in the country. The rising rate of insecurity in the country is threatening its corporate existence as a single indivisible entity and calling to question the legitimacy of the President and Commander in Chief of the Armed Forces. To this end, the need to adopt a socio-political cum military approach to fight against insecurity in the country.

1) Political Sincerity: In this new approach to quell the rising level of insecurity in the country, there is the need for the political class and elite to answer this question as a first step. Are we genuinely ready to end insecurity in the country? An objective and sincere response to the question will halfway solve the challenges of insecurity in the country. The political class, especially the federal government, must show sincerity in its fight against insecurity in all parts of the country. An example is the recent call on the President by the National Assmly and

\section{$(c))$ BY-SA}

This work is licensed under a

Creative Commons Attribution-ShareAlike 4.0 International License. 
security Chiefs to declare bandits in the north a terrorist group. Some parts of the country have complained of the Federal Government's insincerity in handling the crisis. The recent utterances of the minister of Justice and Information on insecurity in the country have further fueled negative perceptions of the government's fight against insecurity in the country (see all Nigerian Newspapers of October 22, 2021).

2) Political Collaboration: There should be strong collaboration between the three levels of government in the fight against insecurity in the country. The local, state and federal governments must work in partnership to defeat insecurity. A situation where the southern Governors have a position different from the Federal Government and their northern counterparts would endanger the country in its quest to end insecurity (The Guardian, May 12, 2021). Also, the three arms of government (i.e. the Legislature, Executive and Judiciary) must be on the same page if the government wants to win the fight.

3) Security Collaboration: There should be a more coordinated synergy among the country's various security outfits and operations. The military, paramilitary and multi-national Joint Task Force and local security outfits must work purposively together to end the rising insecurity in the country. There should be a coordinating centre for all the security agencies involved in the fight at all levels in the country.

4) Mass Reorientation: There is the need for a sincere mass reorientation of Nigerians to win the fight against insurgency in the country. The reorientation program should be driven by religious leaders, traditional institutions, leaders of thoughts, educational institutions and subnational leaders. The reorientation will enable Nigerians to see the need to partner with the government in making the country safe for all. The mass orientation should be a national campaign (The War Against Indiscipline between 1983 to 1985).

5) True Federalism: The country's restructuring in line with best federal practices will bring an end to most agitations in the country. There is an urgent need for the various federating units in the country to sit and agree on some basic issues threatening the country's corporate existence. The issues of resource control, perceived marginalization, devolution of power, the establishment of state police, amongst others, if addressed, will quell the rising level of insecurity in the country.

6) Constitutionalism: The rule of law should be respected by all in the country. Every part of the country and its citizens should be treated equally in government appointments, development programs and the fight against corruption. The government and security agencies must operate within the ambit of the law. The root of the Boko Haram insurgence is traceable to abuse of the rule of law. There should be good governance and accountability at all levels of government. The principles of separation of powers; and checks and balances should be upheld in the country. It will imbibe in the citizens a sense of belonging and hope in the country. One major reason citizens take arms or agitate against the state is the lack of sense of belonging and hope.

7) Credible Electoral Process: The result cannot be right until the process is right. The Nigerian State and Nigerians must take pragmatic steps to ensure the electoral process is credible and votes count during elections. When votes count, the elected will be answerable to the electorate, which will lead to development. If the country gets its electoral process right, a development would lead to a better standard of living and create more employment. It will reduce insecurity because there will be a sense of satisfaction among youths used against the State.

\section{CONCLUSION}

The study revealed that military offense and onslaughts have not quelled the rate of insecurity in the country for over a decade. There is an increase in criminal activities across the country. There is a need for the government to look into these policy recommendations and adopt them to abate the challenges of internal security in the country.

\section{REFERENCES}

Adeniyi, P. (2010). Nigeria: Yesterday, Today and Tomorrow. Ibadan: Daily Graphic Limited. Duerksen, M. (2021). Nigeria Diverse Security Threats. Africa Center for Strategic Studies.

\section{$(\infty))$ BY-SA}

This work is licensed under a

Creative Commons Attribution-ShareAlike 4.0 International License. 
Etebom, J. (2021). Long Years of Military Rule in Nigeria: A Blessing or A Curse. Jorurnal of Public Administration and Governance.

Goggins, D. (2017). Biafra Separatist Movement in Nigeria. Retrieved from The Researcher: www.legalaidboard.ie

Guardian, T. (n.d.). Retrieved from The Guardian Nigeria: www.guardian.ng>news, retrieved on October 15, 2021

Haldun, C., \& Opeyemi, A. (2011, August 8). Ethnic and Religious Crisis in Nigeria: A Specific Analysis upon Identities (1999 - 2003). Retrieved from www.accord.org.za

Mustapha, A. (2005). Ethnic Structure, Inequality and Governance of Public Sector in Nigeria. Centre for Research on Inequality, Human Security and Ethnicity.

Segun, J., Gberevbie, D., \& Kester, O. (2020). Building Security through Insecurity: The Nigerian Military and Counter - Violence Campaigns in the Fourth Republicr, retrieved from Sage Journals: journals.sagepub.com/home/afs

Sylvanus, I., Ebohon, \& Emmanuel, U. (2012). Managing the Problems of Public Order \& Internal Security in Nigeria. Retrieved from Tandfonline: www.tandfonline.com/101/uafs20

Premium Times. (2021, September 14), retrieved on October 25, 2021

Vanguard. (2017, May 10). Ethnic Groups in Nigeria, retrieved on November 1, 2021

Vanguard. (2021, April 26). Retrieved from vanguardngr.com, retrieved on November 7, 2021

Vanguard. (n.d.). Defend Yourselves or you will all Die, TY Danjuma tells NIgerians. Retrieved from Vanguard Nigeria: www.vanguardngr.com, retrieved on November 13, 2021 